\title{
Indicators of Dental Status as The Reference Test System the General Adaptation Syndrome
}

\author{
Prikule DV, Alexandrov MT*, Kukushkin VI, Pashkov EP, Achmedov AN and Namiot ED \\ Scientific and Clinical Center for the Rehabilitation of Women's Health, Russia
}

*Corresponding author: Alexandrov MT, Scientific and Clinical Center for the Rehabilitation of Women's Health, Russia.

Received Date: March 04, 2019

Published Date: March 28, 2019

\section{Introduction}

It is known that the idea of stress as a factor, which characterizes the manifestations of the general adaptation syndrome (GAS) of the organism, was formulated by the scientist Hans Selye in 1936 [1,2]. As a result of numerous studies, it was found that under the influence of stress (stress stimulants according to Hans Selye) as negative factors that threaten homeostasis, there is a mobilization response of organs and systems organism at all levels of its organization [35]. The most extensive study of GAS conducted in respect of the cardiovascular system [6-8]. At the same time, objective data on the reference indicators characterizing the condition of the organs of the maxillofacial region in GAS at stressful loads in the world literature is extremely under-lit. This prevents the development and clinical application of medical technologies sanogenetically aimed at normalizing the state of maxillofacial region homeostasis when exposed various stressors-physical, chemical and biological factors at various levels of its morphofunctional organization. Based on this concept, we noticed that the program of training students in higher education includes periodic modular control classes that significantly affect to change the physical and psychosomatic state of students [6,9-12], which requires studying presented problem directly related to GAS (stress). It is known that a long stay in conditions of stress can be the cause of pronounced emotional imbalance and increased anxiety [9]. Specified psychosomatic destabilized status of future young professionals may further affect their effectiveness of the professional activity and the level of socialization in society [13-15].

At the same time, it is known that modern advances in the field of medical technology in dentistry allow us to carry out relevant research (electrical donation diagnostics, thermometry periodontal, pH-metry and fluorescent diagnostics saliva) without the need to create special conditions for fulfillment [5,6,16-23], which, apparently, can be used to assess the state of GAS of students under stress. The recieved information from these types of studies, in our opinion, will allow using this data for objective substantiation, assessment and correction of GAS (stress) based on identifying initial, basic signs of dysfunction tissues and organs of maxillofacial region. Such a methodological approach is practically not reflected in the domestic literature and is of scientific and practical interest. Thus, in accordance with the presented concept, the development of an algorithm for complex and express diagnostics state of GAS under the influence of stress (educational process) on the body through the study of biocomplication of a number of objective factors: metabolic (fluorescence diagnostics and $\mathrm{pH}$ of saliva), morphofunctional (test barbell, formula Sheikh-Zade), functional (EDI, thermometry periodontal) and psychological (test of C.D. Spielberger) characteristics of tissues and organs of maxillofacial region seems to be relevant. The purpose of research: experimental and clinical justification of the method of complex and rapid diagnosis of stress as a manifestation of AOS in students on metabolic, morphometric and functional parameters of tissues of the maxillofacial region. Materials and methods. The study involved 30 students aged 18 to 21 years (17 females and 13 males) in the period before and after training sessions with mental stress, after physical exertion, as well as after the end of the first year of study, at the beginning and in the middle of the first semester of the second year of study.

\section{Material and Methods}

The study involved 30 students of I and II course of dental faculty at the age of 18 years old to 21 years old (17 females and 13 males) before and after training sessions with mental exertion, after physical exertion, and after the end of the first year of study, at the beginning and the middle of the first semester of the second year of study. Statistical analysis of the results was performed using standard statistical complexes in Microsoft Excel. To determine the degree of conduction of nerve receptors of the tooth pulp was used the method of electroodontodiagnosis using an apparatus "Pulp EST" from company "Geosoft" (Russia) before, after training with mental stress and after physical unloading. In this study, passive 
electrode was fixed on the lip of the investigated. The working surface of the active electrode was placed on the middle of the cutting edge of the front teeth. A minimal amperage was applied and when the first sensations appeared the study was stopped. Diagnostics were carried out for three times for each subject and the lowest value among all received was chosen [5].

While studying the indicators of heat transfer and metabolism in the body at the end and beginning of the school year, we used the method of tissue thermometry periodontal using semiconductor thermometer TEMP-1 (Russia), exploring the temperature of periodontal tissues, placing the sensor apparatus in areas of marginal gum of the anterior upper jaw for 1-2 minutes [20]. To study the level of metabolism and the acid-base balance of the body of students at the end of the school year, after the summer holiday period and in the middle of the first semester of the next year of study, the determination of the $\mathrm{pH}$ of saliva was applied using the indicator litmus paper with an indicator scale and a pH meter [20]. In order to identify the level of porphyrins in the samples of saliva (metabolic rate indicator tissue respiration and metabolic rate), studied at the beginning of the school day, after class with mental load and after a night rest, fluorescence spectra were measured (according to the method of prof. Aleksandrov M.T) using a portable Raman-luminescent spectrometer of the company "Spectr-M" with built-in solid-state Nd: YAG laser (wavelength 532nm) [17]. With the aim of a comprehensive assessment of physical activity and the adequacy of the oxygen balance of the body the Shtange test was carried out. To implement these samples before and after exercise with mental stress, and after physical exertion, the students were also asked to take 2-3 deep inhalations and exhalations, and then after a deep exhalation, hold their breath, with the time fixed by stopwatch [21].

For the ability to assess the characteristics of the morphofunctional state of the body as a result of the exposure to stressors before the start of the school day, after the period with mental stress and after physical discharge the formula of SheikhZade was used: $\mathrm{S}=\mathrm{f} \cdot \mathrm{PAD} \cdot \mathrm{M} 1 / 3 \cdot \mathrm{K}$, in which $\mathrm{S}$ (standard units) is stress level, $\mathrm{f}(\mathrm{min}-1)$ is heart rate, PAD ( $\mathrm{mm} \mathrm{Hg}$ ) is pulse blood pressure, $\mathrm{K}$ - normalizing factor: 0,8244 - 10-4 (for male) and 0.9357 - 10-4 (for female), M (kg) - body weight [23]. While determining the emotional (psychological) state of students associated with the current situation at the end of the school year, at the beginning of the current year of study and after classes with mental exertion the personal and situational anxiety was revealed by the method of C.D. Spielberger [24,25].

\section{Research Results}

According to theresults of theanalysis of electroodontodiagnosis, obtained from students after the end of classes with mental load an increase in the conductivity index of nerve pulp receptors tooth by $46.5 \%$ was revealed ( $p<0.01$ ) compared with a similar study conducted before the start of the educational process. At the same time, while conducting electroodontodiagnosis after period of physical unloading (physical culture, moving to another university educational base) there was a tendency of normalization of electroodontodiagnosis values by $23.2 \%$ ( $p<0.05$ ). The results obtained are indirectly combined with the provisions of the neurotrophic theory of caries Entin DA (1935 g) and the results of an experimental study on the effect of stress on metabolic processes in the pulp of the tooth, held by Ostrovskaya I.G. [26, 27]. It is known that during prolonged exposure to stress, not only metabolic shifts, but also structural changes in the pulp of the tooth happen, occurring due to destabilization of the functional state of the central nervous system and disruption of corticotal bonds, followed by violation of trophic processes in the tissues of the teeth. Consequently, conducting the method of electroodontodiagnosis allows you to establish the initial symptoms and to carry out dynamic monitoring of the severity of the effect of stress on the body. It has been established that the indicator of the temperature of the surface of the body and the mucous membrane of the oral cavity indicates not only the state of heat transfer activity, but also on the level of blood flow and metabolism in the body of the investigated [28]. In a comparative analysis dynamics of thermometry values of periodontal tissues, conducted on students at the end of the first and the beginning of the second year, an increase of $0.62{ }^{\circ} \mathrm{C}(\mathrm{p}$ $<0.001$ ) was found. Thus, the possibility of correction of the effects of stress on the body in the form of dynamics to the normalization of thermolysis is established, and, indirectly, metabolism due to the presence of the rest period for 1.5-2 months. It is known that the rational ratio of the components of the acid-base balance contributes optimal functioning of metabolic processes and increases the body's resistance to various pathological effects, including stress.

At the same time, the negative effect of increased acidity on the immune system and functional properties of the systems organism is determined. As a result of studying the $\mathrm{pH}$ of students' saliva after the first year of study the values of $6.41 \pm 0.19$ were identified, and after two months summer holiday the dynamics to normalization process were observed with the acid-base balance up to indicators equal to $6.87 \pm 0.11$. Therefore, there was a recovery normal $\mathrm{pH}$ balance as a result of the rest period. However, when measuring the $\mathrm{Ph}$ indicators received from the same contingent studied midfirst semester of the new school year values corresponding to $6.63 \pm 0.11$ are determined. Thus, the absence of stress on the body of students for two months allows to normalize the ratio of acidbase balance, and already two months after being in under stress, there is a dynamic to destabilize the specified condition. As a result of numerous studies by a number of authors, it has been revealed that an increase in the number porphyrins in tissues and biological fluids occur due to the disturbance of oxidative processes in the body under conditions associated with hypoxia, with a state of decompensation of the cardiovascular system, nervous overstrain, i.e. those phenomena that may occur due to prolonged exposure to stress $[25,26]$. One of the most promising types of research for these purposes is the non-invasive method.

laser fluorescence diagnostics [16,29,30]. When measuring fluorescence spectra of the students' saliva samples after being on lessons to comparison with the results of the similar research at the beginning of the school day the high-intensity fluorescence in the range wavelengths of 600-650 $\mathrm{nm}$ with increasing integral intensity 10-30 times individually was recorded (Figure 1). This result indicates an increase of porphyrin compounds in the studied 
saliva samples. It should be noted, that fluorescent diagnosis of saliva samples from the same number of pupils after a night rest the following day revealed a decrease in the degree of luminescence intensity by a factor of 7-10 compared with the result obtained at the end of the previous school day (Figure 2). Thus, we observed a decrease in the severity of stress on the body. after a day of rest. At the same time, the possibility of express diagnosis of the presence of symptoms stress and the degree of their relief by fluorescent indicators is revealed. Dynamic observation confirmed the obtained results.

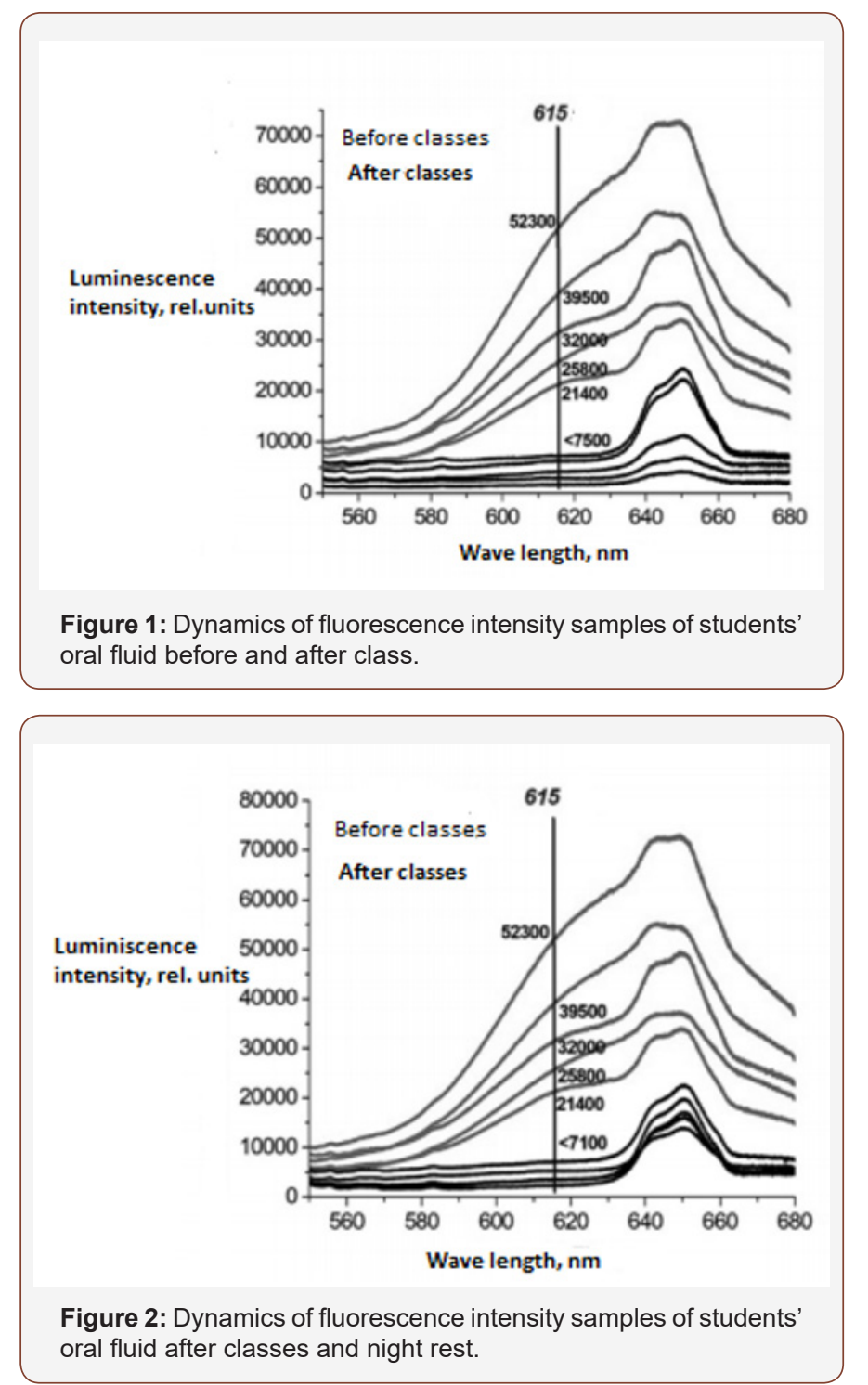

In order to determine the level of oxygen provision in the body of students, a Stange test was carried out, as a result of which a deterioration of the sample performance by $31.5 \%(\mathrm{p}<0.001)$ was observed after the end of two studies followed by recovery of values by $19.3 \%$ ( $p<0.001)$ after a period of physical discharge. When calculating the level of stress in students Sheikh-Zade an increase of the corresponding indicator by $57.2 \%$ ( $p<0.001)$ was set after educational process after the two lessons. Measuring the indicators of the same contingent of students being under the conditions of physical unloading, allowed us to ensure the dynamics of normalization of this level by $18.6 \%$ ( $p<0.05)$. During the Spielberger psychological test held two months after the summer holiday the middle level of personal anxiety prevailed among all the students, despite the previous rest. At the same time, within a similar research carried out for the students after classes with mental stress at most cases a high level of reactive anxiety is revealed. From the presented it follows that in the application plan, the question about the urgent need to apply the method psychoemotional unloading of students in conditions of the school year is relevant (Figures 1\&2).

\section{Conclusion}

Thus, these survey methods can be reasonably included in the method of complex diagnosis of GAS (stress) and its correction in a wide range of students at all stages of academic process. The presented indicators of the maxillofacial area (metabolic, morphofunctional, functional, psychological) objectively and multifactory reflect dental status of maxillofacial area and can be used as refereny in the evaluation of GAS (stress) and its correction.

\section{Acknowledgement}

None.

\section{Conflict of Interests}

The authors declare no conflict of interest.

\section{References}

1. Sel'e G (1960) Essays on the adaptation syndrome [Ocherki ob adaptatsionnom syndrome]. Medgiz, Moscow, Russia.

2. Sel'e G (1992) Stress without distress [Stress bez distressa]. Meditsina, Moscow, Russia, pp. 104-109.

3. Aleksandrovskiy Yu A (2000) Border mental disorders [Pogranichnye psikhicheskie rasstroystva]. Meditsina, Moscow, Russia.

4. Gorizontov PD, Belousova OP, Fedotova MI (1988) Stress and blood system [Stress I sistema krovi]. Meditsina, Moscow, Russia, pp. 5-79.

5. Efanov OI, Dzanagova TF (1980) Physiotherapy of dental diseases [Fizioterapiya stomatologicheskikh zabolevaniy]. Meditsina, Moscow, Russia, p. 41.

6. Marishchuk VL, Evdokimov VI (2001) Behavior and self-regulation of a person under stress [Povedenie Isamoregulyatsiya cheloveka $\mathrm{V}$ usloviyakh stressa]. Sentyabr, St Petersburg, Russia, 52-60, 81-85.

7. Meerson FZ (1987) Adaptation of the body to stressful situations and the prevention of cardiac arrhythmias. Uspekhi fiziologicheskikh nauk 8(4): 56-79.

8. Strygin KN, Poluektov MG (2015) Modern ideas about stress and the protective role of sleep. Meditsinskiy Sovet 5: 70-76.

9. Averina AO, Phedoseeva VI (2016) The study of the manifestations of academic stress in the lives of students. Nauchno-metodicheskiy elektronnyy zhurnal Kontsept 46: 8-12.

10. Shemyakina 00 (2012) Analysis of the causes of stress and methods for its prevention. Psikhologiya I pravo 2: 122-132.

11. Shcherbatykh Yu V (2000) Examination and student health. Vysshee obrazovanie v Rossii 3: 111-115.

12. Shcherbatyh Yu V (2006) Psychology of stress and correction methods [Psikhologiya stressa I metody korrektsii]. Saint Petersburg, Russia.

13. Bodrov VA (1996) Cognitive processes and psychological stress. Psykhologicheskiy zhurnal 17(4): 64-74.

14. Aghajanyan NA (2005) Stress and adaptation theory [Stress I teoriya adaptatsii]. IPK GOU OGU, Orenburg, Russia, 60-94.

15. Sudakov KV (1998) Individual resistance to stress [Individual'naya ustoychivost' k stressu]. Moscow, Russia, pp. 3-268. 
16. Aleksandrov MT (2008) Laser clinical biophotometry (theory, experiment, practice) [Lazernaya klinicheskaya biofotometriya (teoriya, eksperiment, praktika)]. Tekhnosfera, Moscow, Russia.

17. Aleksandrov MT, Zuev VM, Kukushkin VI, Karseladze AI, Ishchenko AI, et al. (2013) The study of the spectral characteristics of the pelvic organs in women and their clinical significance. Onkoginekologiya 3: 63-67.

18. Bilinsky II, Dobrovolskaya MK, Bilinsky A Ya (2017) Changes in the biochemical properties of saliva and their effect on the dental status of students under the influence of stress. Naukovi pratsi VNTU 1: 1-6.

19. Block B (2010) Levels of wakefulness and attention. Experimental psychology [Urovni bodrstvovaniya I vnimanie. Eksperimental'naya psikhologiya]. Moscow, Russia, 3: 7-146.

20. Danilevskiy MF, Borisenko AV (2000) Periodontal disease [Zabolevaniya parodonta]. Health, Kiev, Ukraine, Europe.

21.Zabolotsky IB, Ilyukhina VA (1995) The physiological basis of the differences in stress resistance of a healthy and sick person [Fiziologicheskie osnovy razlichiy stressornoy ustoychivosti zdorovogo I bol'nogo cheloveka]. Krasnodar, Russia.

22. Korkushko OV (2003) Cardiovascular system and age (clinical and physiological aspects] [Serdechno-sosudistaya sistema I vozrast (klinikofiziologicheskie aspekty)]. Meditsina, Moscow, Russia.
23. Sheikh-Zade Yu R, Zuzik Yu A (2001) Determination of the proper heart rate in a person at rest. Fiziologiya cheloveka, 27(6): 114-116.

24. Ustyuzhaninova NV (2004) Functional state of external respiration of healthy students. Byull SO RAMS 1: 134-137.

25. Batarshev AV (2003) Psychology of personality and communication [Psikhologiya lichnosti I obshcheniya]. Gumanit. izd. tsentr VLADOS, Moscow, Russia.

26. Danilova NN, Krylova AL (2002) Physiology of Higher Nervous Activity [Fiziologiya vysshey nervnoy deyatel'nosti]. Rostov n/D: Feniks, pp. 406-407.

27. Erofeeva LM, VavilovaT.P, Ostrovskaya IG (2010) Structural and functional characteristics of the pulp of the teeth of rats in conditions of emotional and cold stress. Morfologiya SPb Eskulap 137(4): 74.

28. Manuylova EV, Mikhalchenko VF (2013) Modern problems of science and education [Sovremennye problemy nauki I obrazovaniya]. 2: 115118.

29. Gorenkov RV, Karpov VN, Rogatkin DA, Shumskiy VI (2007) Chronic hypoxia as one of the factors of increased fluorescence of endog- enous porphyrins in living biological tissues. Biofizika 52(4): 711-717.

30. Rogatkin DA (2000) Laser medicine [Lazernaya meditsina]. 4(1): 30-35. 